\title{
DPF2 wt Allele
}

National Cancer Institute

\section{Source}

National Cancer Institute. DPF2 wt Allele. NCI Thesaurus. Code C157308.

Human DPF2 wild-type allele is located in the vicinity of $11 q 13.1$ and is approximately 19 $\mathrm{kb}$ in length. This allele, which encodes zinc finger protein ubi- $\mathrm{d} 4$, is involved in histone binding and modification. Mutation of the gene is associated with Coffin-Siris syndrome 7. 